\title{
Science Technology Engineering and Mathematics (STEM) Education Approach against a Microscopic Representation Skill in Atom and Molecule Concept
}

\author{
Asih Widi Wisudawati ${ }^{\mathrm{a}, *}$ \\ aDepartment of Chemistry Education, Faculty of Science and Technology UIN Sunan Kalijaga Yogyakarta \\ *Corresponding author: asih.wisudawati@uin-suka.ac.id
}

\begin{abstract}
The aim of this research in to know microscopic representation change in atom and molecule concept which is influenced by STEM Education. This research is one of the sequences in Research and Development of test instrument by chemistry software. The kind of this research is fieldwork research with one group pre-test and post-test design. Subjects in this research are the twenty-seven students in MBS Senior High School grade $11^{\text {th }}$ in Yogyakarta region. STEM Education can improve student microscopic representation skill from 30.18 to 54.62 in average score and based on student result in painting molecule with ChemDraw and Avogadro's application, there are a lot of improvement in understanding concept.
\end{abstract}

Keywords: STEM education, microscopics representations, atom and molecule

\section{INTRODUCTION}

Education in the cluster Science Technology and Mathematics Engineering (STEM) Education absolutely have vital implication in national resilience and economics so that need reformation in science education related with engineering, technology and mathematics [1]. In encounter global economics movement, education necessary to prepare human resources whom has competitive skill. Education in Indonesia have to provide resources to support teaching and learning which refer to the improvement in science, technology, engineering and mathematics competence and career by STEM Education approach.

STEM Education is an approach to multidisciplinary study where there is a concept of integration between the concept of science technology engineering and mathematics. STEM Education form the core technological underpinnings of an advanced society, a key to producing and sustaining this new workforce is improving STEM Education in our country [2]. When student understand about complex problem by the learning in the class, they might have a solution in solving the problem in their life.

Problems of education in Indonesia are currently very quaint. There are factors that affect the quality of education in Indonesia. Curriculum 2013 as a solution offered by the Government in preparing students who are able to compete in the global world. A very good concept in 2013 curriculum has accepted by many parties, yet in implication did not get maximum achievement. Teacher preparedness and infrastructure are the reason presented in curriculum implementation in 2013.

STEM Education has been implemented in different countries, one of which is a country of Japan who developed hybrid school implements a special STEM education. Spirit of the curriculum 2013 contained in STEM Education. If the implementation of the curriculum 2013 using STEM Education will be able to facilitate teachers in the learning process in the classroom. Implementation of STEM education will be increased interest students to carry out inquiry as are requested in the curriculum of 2013.

Modern boarding schools MBS Yogyakarta has the management pattern in the learning in the classroom is good enough with his protégé participant characters who are very active and have the curiosity is very high with the ethics of good behavior. Based on a diagnostic test in the previous research that measures the ability of a microscopic representation of a spiritual attitude and as accompanist to the effects of chemical learning have been implemented in the $10^{\text {th }}$ grade of MBS senior high school in Yogyakarta are presented in Figure 1. The image shows from 10 reserved accompanied reasons examined, students still belongs to the microscopic level representations have the ability. However, according to Johnson, there are three basic capabilities a must has students in learning chemistry, i.e. the capability of representation of macroscopic, microscopic and symbolic. 


\title{
Percentage of the students
}

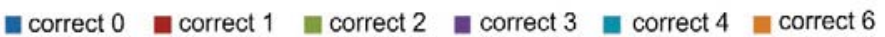

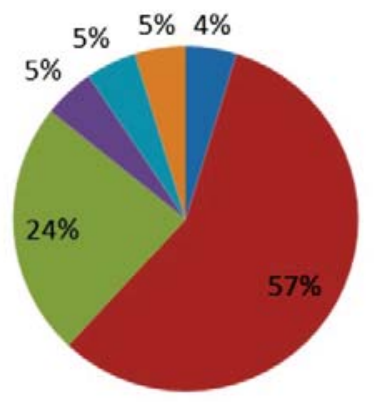

FIGURE 1. Charta Percentage Number of Students with True Reasons in MBS Senior High School in Yogyakarta at 2015/2016 Academics years

Learning chemistry is part of the natural sciences (the science) that can be implemented by using the approach to STEM Education.Learning in chemistry can be conducted bu utilizing the existing materials in the environment around the students and can improve the ability of logical thinking and stimulate students to be able to find the concept of chemistry [3]. The student's thinking ability in the water molecule shape represent in high school who belong to the MBS is low. STEM Education is one of the solutions to improve thinking ability students in the presenting of atoms and molecules. This research will be to design a learning based on STEM education approach in the improvement of the ability of a microscopic representation of atoms and molecules.

STEM Education in preparing students to be competed in the $21^{\text {st }}$ century should have competence of Critical Thinking, Creative Thinking, Collaborative Skill, Communication Skill and Self Education [4]. STEM Education in the achievement of the HOTS (Higher Order Thinking of Skill) or high level thinking patterns on materials chemistry that has the characteristics of a typical. Chemistry requires the students to have the ability representation in his understanding. Representation of Macroscopic, microscopic and symbolic representation is a three that should be owned by the students. STEM Education is one of the alternatives within the classroom management that can be implemented the teacher in preparing students ready to face life and solutions for improving the quality of education in Indonesia.

Chemistry is the science that studies the structure of the material, composition, energy, and material changes that accompany. Constituent structure in teaching materials, an educator should be able to provide a model. Modeling of a chemical material abstract and complex will make it easier for students to understand the material. Educators who provide modeling in the process of learning chemistry can develop mental models of students.

The development of mental models of students can be reflected into the level of representation. According to [5] three levels of chemical representation is a macroscopic, microscopic, and symbolic. Representation of a chemical is the chemical concept representations especially related to constituent structure visualization of a material. Microscopic representation is a representation of the chemical description of structures and processes at the level of the macroscopic phenomena against particles had been observed. The concept of chemistry most tangible representation of a real phenomenon, for example, the concept of atoms, ions, and molecules. In understanding these concepts, students must have a mental model. Mental model of students built from experience, many, and empirical research while studying the concept of Chemistry [5].

Understanding Chemistry is built from two levels namely the macroscopic and microscopic, as does the kekule benzene structure analogy making as grubs biting its own tail so that the resulting model Kekulé [6]. The analogy that was developed by chemists like Kekule aims to facilitate people who studied the structure of benzene. In order to explain the macroscopic phenomenon such as chemical phase of water changes needed concept study microscopically. Microscopic studies can be done in a way to make analogies and models. Analogies and modeling are tools of thinking [6]. The analogy is a process chemical concept 
visualization objects or everyday experience found students, whereas the modelling is a way to describe and explain the objects that cannot be seen such as atoms and molecules.

STEM education has been frequently called as a meta-dicipline, the creation of a discipline based on the intergration of other disciplinary knowledge into a new "whole". When done appropriately, this approach will have high possibility to improve student achievement in acids and bases concept [7]. STEM education is able to enhance the critical thinking ability of students that can be implemented in all aspects of everyday life and work [7].

The main objective of the study is to know the influence of STEM education to increase the representation of microscopic student class XI in the boarding schools of the modern MBS. The research question is how a STEM Education can affect the representation of material changes in microscopic form of water.

\section{METHOD}

This research is a kind of fieldwork (fieldwork) research design with a quasi-experiment with one group pretest-posttest design as a part of R\&D sequence in development instrument test integration Islam and chemistry. The population in this research is the entire student in MBS boarding senior high schools in Yogyakarta grade $11^{\text {th }}$. The sampling technique used was purposive sampling. Research will be carried out at a first semester in 2016/2017 academic years with subject matter chemical bonds. Instructional design used is 5E learning Cycle Model based on STEM education approach is as follows:

1. Engagement Phase: Digging ability early child and bridging knowledge beginning with the concept that will be studied.

2. Exploration Phase: explore child thought about the concept of using science process skills, namely: observation, measurement, classification, prediction, inference, communication, and collect data

3. Phase Explanation: build the correct concept of the concept that found children

4. Elaboration Phase: children use their new knowledge in understanding problems that different (meaningful learning)

5. Evaluation phase: see the achievement of children (microscopic representation capabilities). The approach STEM used includes the following skills:

1. Science discipline: Students understand the concept of atoms and molecules of some chemical compounds including the concept of chemical bonding, molecular geometry concepts based on the concept of the electron domain theory and the VSEPR.

2. Technology discipline: Students use applications software Avogrado and Chem Draw in learning molecular shape.

3. Engineering discipline: Students work with the software application in the design of some molecules with lowest energy optimization in the process of scaffolding.

4. Mathematic discipline: Students are asked to count the angle formed between the molecule and large angle formed in conditions of minimum energy.

\section{RESULTS AND DISCUSSION}

Microscopic representation is a part of Chemical Triangle Johnston (Macroscopics, sub-microscopis and representational). Student would successfully when firstly they learn by macro level then represent in micro level, after that have been written by symbol. This processes is useful particularly for abstract matter like chemistry. In this research, student learn geometry molecule with software application Avogradro and ChemDraw.

\begin{tabular}{lll} 
& TABLE 1. Recapitulation of Data & Pretest and Postest \\
\hline Description & Pretest & Posttest \\
\hline Average & 30.18 & 54.62 \\
Standard Deviation & 11.64 & 24.13 \\
Lowest Score & 5 & 0 \\
Highest Score & 55 & 100 \\
\hline
\end{tabular}

TABLE 2. Paired Samples Test both Pretest and Posttest in Measurement Microscopics Representation

\begin{tabular}{|c|c|c|c|c|c|c|c|}
\hline Mean & $\begin{array}{l}\text { Std. } \\
\text { Deviation }\end{array}$ & $\begin{array}{l}\text { Std. } \\
\text { Error } \\
\text { Mean }\end{array}$ & $\begin{array}{l}95 \% \\
\text { interval } \\
\text { difference }\end{array}$ & $\begin{array}{l}\text { confidence } \\
\text { of the }\end{array}$ & $T$ & DF & $\begin{array}{l}\text { SIG (2- } \\
\text { tailed) }\end{array}$ \\
\hline-24.44 & 26.61453 & 5.12197 & $\begin{array}{l}\text { Lower } \\
-34.97280\end{array}$ & $\begin{array}{l}\text { Upper } \\
-13.91609\end{array}$ & $-4,772$ & 26 & 0.00 \\
\hline
\end{tabular}


Table 1. shows the change in the average score obtained from students before and after for carrying out the learning process with a repurpose STEM education approach. The students average score of from 30.18 to 54.62 with standard deviation of score from 11.64 to 24.13 . From the use of statistical parametric samples associated with have acquired significance probability 0.00 (two tail) and the $t$ score is 4.772 ( $t>$ table 2.055) so that significantly different for pretest and post-test score.

Qualitative data is shown in the initial diagnostic test is there weakness in understanding the basic concepts of microscopically on atoms and molecules on phase change phenomenon of water. The weakness of the most microscopic representation of imaginary concepts explained kinetic energy changes that accompany the phases (solid/ice, liquid, gas) and describes the distance between the water molecules in three phases (solid/ice, liquid, gas) and pictures. Students demonstrate understanding of the concept enough to explain the motion of the particles of water in three phases in the visualization of the image (the movement of the particle). The data is the end result of the design of molecular geometry made students already more than $50 \%$ with guidance and repetition more than two times.

STEM Education is one approach in the learning process of science that emphasized the existence of integration of various scientific disciplines. This Integration process is indispensable in an order of the learning process as it will be able to equip a child to become a generation of literate science. The ability and competence of children to be able to survive in the $21^{\text {st }}$ century can be enhanced through the approach STEM. The $21^{\text {st }}$ century skills include the skill of self-confidence, technology, life and career skills, collaboration skills, communication skill is nothing academic influence on students with STEM Education.

Implementation approach to STEM Education focuses on hands on activity students. The learning process was centered on students which are the students learn the concept or theory about the shape of atoms and molecules by using an application or software ChemDraw and Avogadro. The process of learning had done in the computer lab with two students to one computer so they can collaborate and discuss in predicting molecular shapes. The learning process in this study uses the syntax of the $5 \mathrm{E}$ learning circle so that it can be sorted located STEM aspects on the clear phase. The sequence of phase is Engagement phase had done, after that, the Exploration Phase, Explanation, Elaboration Phase, and Evaluation phase that emphasizes the understanding of Science (chemical concept) by leveraging technology (application of chemdraw and Avogadro) for Designing Molecular shape geometry (engineering) and skills to calculate and predict the angle between atoms and the distance between the molecules that make up a molecule on the conditions of formation of energy minimum.

Students are quite active in the learning process with the approach of the STEM. This is due to the motivation of studying chemistry with applications are not the same between students which appear from there is still the lazy children when asked to make the shape of a molecule with application and then those pupils get score of 0 at post-test. Although there is a lazy pupil when they form of molecule design, most of them include being enthusiastic students when learning with STEM Education based on hands on activity.

Technology is an important aspect in this study. Process visualization a atoms and molecules assisted with application technology will ease the process of understanding the microscopic level students. The visualisation like picture, animation, and simulation can foster student's learning of model-based explanations of the sub-microscopics world and powerful tools for teaching and learning chemistry [8]. This research is highly relevant to the research that has been done before. The results of this research are using dynamic visualization with applications of ChemDraw and Avogradro based on quantitative and qualitative data collected to increase understanding of the sub microscopic representation of students on the concept of understanding the shape of the molecules of chemical compounds. This result was supported by other research which emphasize effective learning at a relational level of understanding requires simultaneous use of submicroscopic and symbolic representations in chemical explanations [9].

Visualization can help the understanding of the chemical processes tend to be on certain abstract materials. Modelling with computer application is make bridge between reality (original) and reality (concrete model). This mental model should be preliminary for the students in Piaget's development stage of concrete operation. In the process of learning that uses visualization must be the process of review of the teacher in order to keep from the wrong understanding on students.

\section{CONCLUSION}

Research in implementation STEM Education to measure microscopic representation has been done with any completion in the further research. This research can be drawn conclusions that STEM Education can enhance the microscopic representation of students based on the increase in the average score close to 
students from 30.18 became 54.62 with in significantly different from the value $\mathrm{t}$ counted $>\mathrm{t}$ table. Based on qualitative data the results of the work of students in drawing application with ChemDraw molecules and Avogadro have appeared achievement of microscopic representation with appropriated understanding.

\section{ACKNOWLEDGMENTS}

The researcher would be pleased to UIN Sunan Kalijaga through LPPM has provided support funding for the implementation of this research. Researchers also say thanks to all the teachers and students from MBS Senior High School in Yogyakarta Region.

\section{REFERENCES}

1. C. D. Denson, C. Hailey, C. A. Stallworth and D. L. Householder, Int. J. STEM. Educ, 16, 1, 11-15 (2015).

2. C. C. Meng, N. Idris, and L. K. Eu. EURASIA, J. Math. Sci. Tech. Ed. 10, 3, 219-227 (2014).

3. N. Koga. A multidisiplinary and Comprehansive Chemistry Teaching or Learning for Next Generation. In: Proceeding of ISCE (The first of International Seminar on Chemical Education 2015 UII, Yogyakarta, 2015).

4. E. Trnove and J. Trna, Procedia: Sosial and Behavioral Science, 167, 184-189 (2015).

5. N. D. A. Halim, M. B. Ali, N. Yahaya and M, N, H. M. Said, Procedia: Sosial and Behavioral Science Proceeding, 97, 224-228 (2013).

6. A. G. Horrison and R. K. Coll, Analogi dalam Kelas Sains (Panduan FAR-Cara Menarik untuk Mengajar dengan Menggunakan Analogi) Translated by Akhlis Nursetiadi (PT Indeks, Jakarta, 2013).

7. S. Ceylan and Z. Ozdilek, Procedia: Sosial and Behavioral Science, 177, 223-228 (2015).

8. I. Eilks, T. Witteck, and V. Pietzner, C.E.P.S. J. 2, 1, 125-145 (2012).

9. D. F. Treagust, G. Chittleborough and T. L. Mamiala, Int. J. Sci. Educ. 25,11, 1353-1369 (2003). 